\title{
KYOTO MAP KEY
}

PLACES ASSOCIATED WITH GUNKI

1. Samegai, south of Gojō street; where Gunki lived in rental housing owned by his friend Tomitaya Riemon

2. Intersection of Kiyamachi and Matsubara streets; Gunki's final residence

\section{PLACES ASSOCIATED WITH WASA}

3. Intersection of Shinbashi and Nawate streets; teahouse operated by Wasa

4. Intersection of Higashi-no-tōin and Nijō streets; residence of Wasa's adoptive daughter Ito

PLACES ASSOCIATED WITH MITSUGI

5. Yasaka Kami-chō; Mitsugi's residence

6. Benten-chō off Shimokawara street; where Mitsugi lived with Iori

7. Nijō Shinchi; the brothel where Mitsugi worked

8. Saiin; where Mitsugi first lived in Kyoto

9. Uchino Niban-chō; where Mitsugi's brother and mother lived

10. Katagihara; native village of Mitsugi's adoptive son, Kamon

PLACE ASSOCIATED WITH KINU

11. Nushiya-chō, off Shichijō street; where Kinu lived with her husband

PLACES ASSOCIATED WITH SANO

12. Area in front of Kyoto Daibutsu; where Sano lived with her husband

13. Uma-chō; where Sano lived with Kinu

14. Area on Imadegawa street where Sano's grandparents lived

\section{PLACES ASSOCIATED WITH UMON}

15. Kami Goryō-mae; where Umon worked as an Yijing diviner
16. Sanbongi; where Umon first met Gunki

PLACES ASSOCIATED WITH GUNKI'S FRIENDS

17. Intersection of Akezu and Matsubara streets; residence of Nakamuraya Shintarō

18. Intersection of Akezu and Gojō streets; residence of Kamaya Kyūbei

19. Chion'in Furumonzen Moto-chō; residence of Tsuchiya Shōni

20. Rental horse grounds north of Gionsha; where Shōni first met Gunki

21. Butsuguya-chō on the north side of Kitakōji street; residence of Hōki Masasuke

22. Intersection of Nishi Ishigaki and Shijō streets; residence of Matsusakaya Nihei

23. West side of the Takase River, south of Matsubara street; residence of Minoya Kohachi

24. Intersection of Yanagi-no-banba and Maruta-machi streets; residence of Teradaya Kumazō

25. Shichiken-chō; residence of Minoya Bunsuke

\section{TEMPLES}

26. Unseiji, intersection of Samegai and Uonotana streets, south of Gojō street; Gunki's temple

27. Daijōin, Nijō street, on the east side of the Kamo River; Wasa's and Mitsugi's temple

\section{OTHERS}

28. Kiyomizu; where Mitsugi and others performed water austerities

29. Nyakuōji; where Mitsugi and others performed water austerities

30. Kyoto Eastern Magistracy

31. Kan'in princely house

32. Nijō house

33. Yamanoi house 


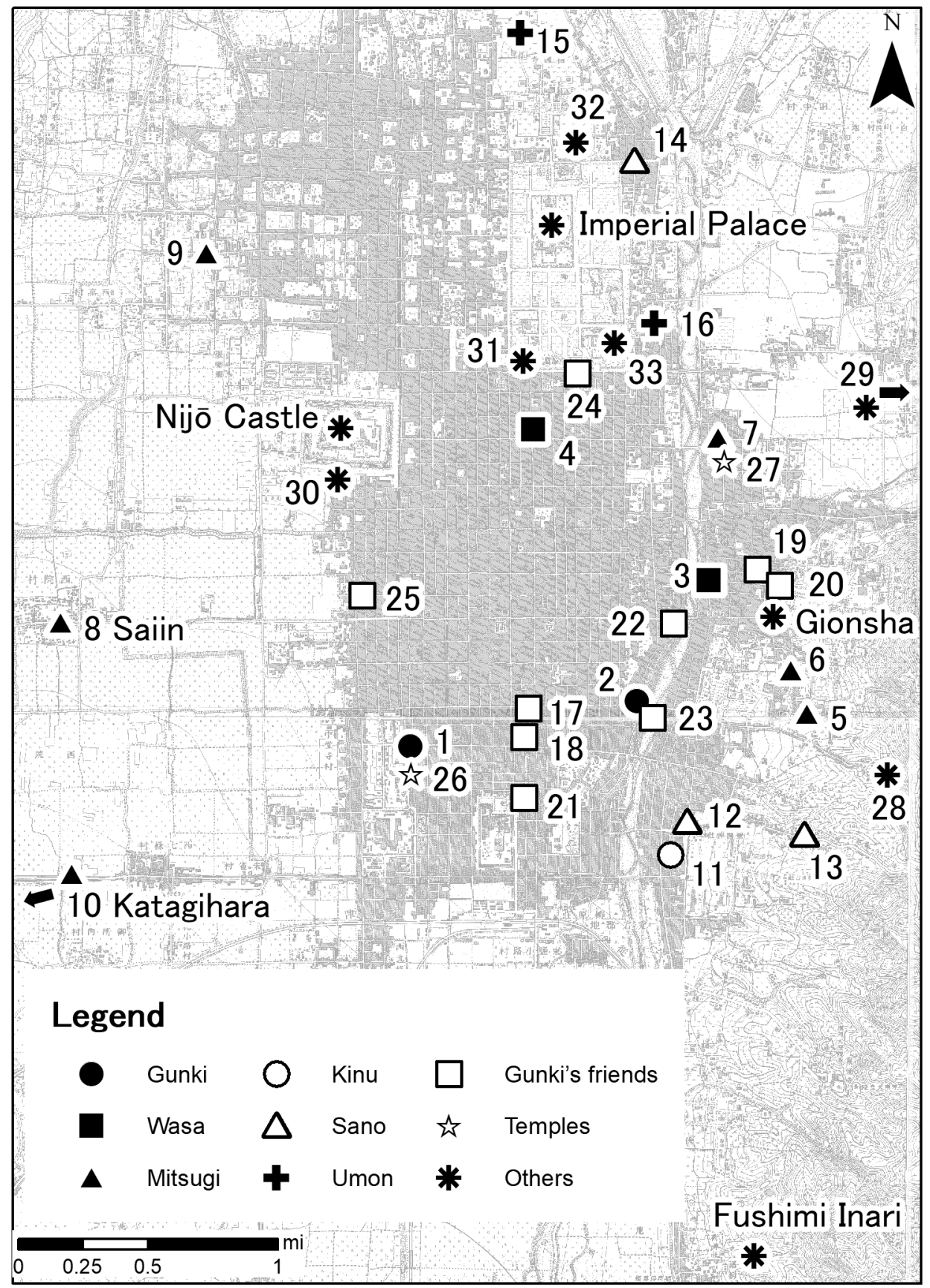

Figure 0.1 Map of Kyoto. Satō Hirotaka. Based on Japanese Imperial Army Survey Corps map of 1887. Ritsumeikan University. 